\title{
DECISION SUPPORT SYSTEM TO ELECT THE BEST USTADZ USING SIMPLE ADDITIVE WEIGHTING METHOD
}

\author{
Muhammad Abdan Syakuro' ${ }^{1}$, Desti Fitriati ${ }^{2}$ \\ Program Studi Teknik Informatika \\ Universitas Pancasila \\ abdan@univpancasila.ac.id, desti.fitriati@univpancasila.ac.id
}

(*) Corresponding Author

\begin{abstract}
Abstrak
Pesantren merupakan sebuah tempat untuk para santri tinggal dan belajar pendidikan agama. Didalam pesantren terdapat sumber daya manusia yang sangat membantu dalam pembelajaran di pondok pesantren yaitu ustadz. Dalam proses mensukseskan pendidikan, adakalanya pesantren perlu melakukan penilaian untuk meningkatkan kualitas pendidikan salah satunya melakukan penyeleksian ustadz terbaik yang memadai dan melebihi rata-rata. Banyaknya ustadz yang ada menyebabkan sulitnya pengambilan keputusan pemilihan ustadz terbaik secara cepat, akurat dan belum bisa memberikan hasil yang maksimal serta membutuhkan waktu yang sangat lama dalam perhitungan. Selain itu, pemilihan ustadz terbaik yang ada di Pesantren Qur'an Al Hikmah Bogor masih belum obyektif dikarenakan pemilihan ustadz terbaik masih ditunjuk secara langsung tanpa menggunakan perhitungan. Berdasarkan permasalahan yang diuraikan diatas maka dibutuhkan sebuah aplikasi Sistem Pendukung Keputusan (SPK) menggunakan metode Simple Additive Weighting untuk membantu dalam melakukan pengambilan keputusan ustadz terbaik di pesantren. Sistem yang dibuat ini merupakan sistem dinamis dimana pengguna dapat mengatur parameter kriteria serta bobot itu sendiri. Disisi lain, Dari pembuatan Sistem Pendukung Keputusan tersebut dihasilkan akurasi sebesar 90\% dari 30 sampel sesuai diantaranya adalah 27 sampel.
\end{abstract}

Kata kunci: Sistem Pendukung Keputusan, Simple Additive Weighting, Pesantren, Ustadz.

\begin{abstract}
Pesantren is a place for students to live and learn religious education. In Pesantren there are human resources that very helpful for learning in boarding school, namely ustadz. In the process of successful education, sometimes pesantren needs to make an assessment to improve the quality of education, one of it is conducting the best selection of ustadz adequate and exceeding the average. The number of ustadz that exist causes difficult decision making of the best ustadz elections quickly, accurately and has not been able to give maximum results and takes a very long time in calculation. In addition, the selection of the best ustadz in Pesantren Qur'an Al Hikmah Bogor is still not objective because the selection of the best ustadz is still appointed directly without using calculations. Based on the problems described above, a Decision Support System (DSS) application is needed using simple additive weighting method to help in making the best ustadz decision in pesantren. This system is a dynamic system where users can set the parameters of criteria and weights themselves. Besides, From the making of the Decision Support System produced accuracy of $90 \%$ of 30 samples according to which are 27 samples.
\end{abstract}

Keywords: Decision Support System, Simple Additive Weighting, Pesantren, Ustadz.

\section{INTRODUCTION}

Pesantren is a place for students to live and learn religious education. Pesantren is also institutionalized in the community, especially in rural areas and is one of the oldest educational institutions in Indonesia (Syafe'i, 2017). Santri and Ustadz are in a place with a good environment and many facilities in pesantren including mosques for worship, dormitories to stay, study rooms, libraries, fields and facilities that support other diverse activities (Usman, Santoso, \& Hidayat, 2017). In addition, there are human resources that are very helpful in learning in boarding schools. Human resources are very important for the development and running of a boarding school because santri in boarding schools can be noble and good character is certainly influenced by several factors, one of which 
is Human Resources (HR) namely ustadz as well as teachers who work in the boarding school (Mundiri \& Zahra, 2017). Ustadz plays a big role in education in pesantren as an effort in the formation of santri character which is an integral part of islamic education orientation. In the world of Education the existence of the role of a teacher is one of the most important factors to advance the world of Education.

Similarly, ustadz in pesantren Educational Institutions is the same as having an important and vital position in developing the world of pesantren. Ustadz is a teacher, teacher and surrogate parent in pesantren. Ustadz is the most important part of learning activities in pesantren both formal education and unformal education. Ustadz who teaches in pesantren must have a noble nature because ustadz in pesantren as a teacher and role model for his students so that the trait must always be maintained in the pesantren environment.

In the process of succeeding education, sometimes pesantren need to make an assessment to improve the quality of education by conducting the best selection of ustadz adequate and exceeding the average. The number of ustadz that exist causes difficult decision-making of the best ustadz elections quickly, accurately and has not been able to give maximum results and takes a very long time in its calculations. In the selection process ustadz in Pesantren Qur'an Al Hikmah Bogor still has some obstacles, namely in the selection process is still appointed by the leadership. The results of the appointment in the best ustadz election will usually be given a gift by the Foundation such as a raise, free umrah, bonus additions and others. So that in the process of selection ustadz best must be completely selected objectively regardless of who the candidate. Therefore, the need for a Decision Support System (DSS) application to facilitate the best ustadz retrieval in a pesantren. Decision Support System itself is very helpful in making decisions that are objective for the interests and needs of pesantren. In the research with Simple Additive Weighting method has been done by Muhammad Defit Saputra with the title of research Implementation of Simple Additive Weighting Method To Select The Selection of Lurah Pondok (Case Study: Pondok Pesantren Al-Munawwir Krapyak Kompleks "L") (Deffit Saputra, 2019). This research discusses about the selection of lurah pesantren that is still problematic, which is lurah pesantren is still chosen based on the subjectifity. Many students who have many acquaintances management in the previous year period so that one way to choose by making acquaintances from the previous period into lurah pondok in the next management period. The purpose of the study is to avoid fraud or objectification factors by creating a Decision Support System with Simple Additive Weighting method.

Based on the problems of previous research and this research, there is one common urgency that is avoiding cheating and unfairness that occurs during elections. This research aims to create a Decision Support System with Simple Additive Weighting method. This method was chosen because it is able to select an alternative best of a number of alternatives. In this case the alternative is ustadz who is entitled to receive the highest appreciation of the best ustadz based on the criteria that have been determined. In addition, Simple Additive Weighting method has an expenditure in the form of perankingan. The results of the warkingan can show who ustadz with the highest and lowest percent value.

\section{RESEARCH METHODS}

This research uses the Simple Additive Weighting as a method. According to , the stages and also the proccess outputing the final ranking from the lowest to highest. Simple Additive Weighting is a method of finding the weighted sum of performance ratings on each alternative of all attributes (Muslihudin, Triananingsih, Kasmi, \& Anggraei, 2017).

\section{Type of Research}

The study will be about Decision Support Systems (DSS) that can help determine the best ustadz selection in pesantren. DSS is designed to solve many problems with effectiveness and productivity with the help of computer technology (Nurdiyanto \& Meilia, 2016).

\section{Time and Place of Research}

This research was conducted in Pesantren Qur'an Al Hikmah Bogor one and also held during the election of the best ustadz in pesantren. Pesantren Al Hikmah Bogor is a pesantren initiated by Ustad Abdul Hasib and its founder is Ustadz Irfan Mujahid who currently still holds the mandate in leading the Foundation of Qur'an Al Hikmah Bogor Pesantren. Pesantren was successful in developing the program from the beginning only tahfid program to have excellent programs such as Super Manzil, Rumah Dhobit, Rumah Mutqin and SIBA (Super Intensive Arabic).

\section{Research subject}


In this research, researchers used original alternative data in pesantren with a total of 15 alternatives. Alternatives are chosen directly by the head of pesantren to be used as a trial. The chosen alternative is the candidate of the best ustadz election in pesantren. The alternatives contain Tabel 1 below:

Table 1. Alternative Data

\begin{tabular}{cl}
\hline No & Alternative \\
\hline 1 & Ustadz Raushan \\
2 & Ustadz Shofwan \\
3 & Ustadz Zaki \\
4 & Ustadz Iqbal \\
5 & Ustadz Apri Yandi \\
6 & Ustadz Arif Maulana \\
7 & Ustadz Endro Suliyanto \\
8 & Ustadz Endrian \\
9 & Ustadz Qolby \\
10 & Ustadz Khusaeri \\
11 & Ustadz Jodi \\
12 & Ustadz Rifqi \\
13 & Ustadz Fuad \\
14 & Ustadz David \\
15 & Ustadz Khairuddin \\
\hline
\end{tabular}

\section{Procedure}

Below these are steps and method used:

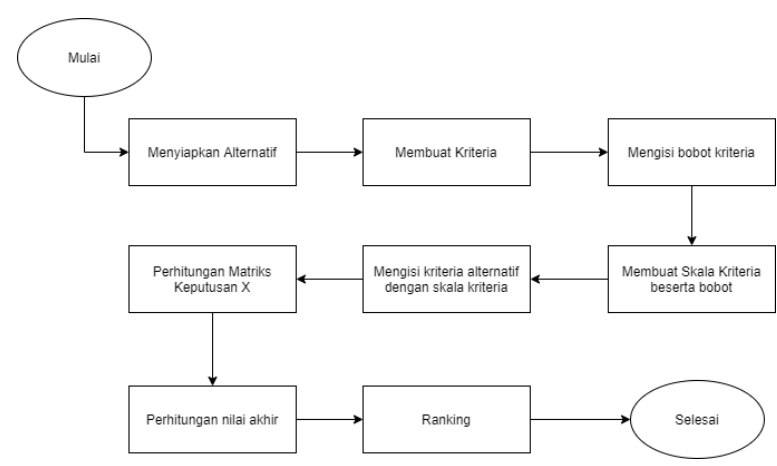

Figure 1. Simple Additive Weighting Steps

In Figure 1 above is a diagram of stages in the use of Simple Additive Weighting method. The first step is to prepare an alternative that will be used as a filling criteria. Next is to create criteria and fill in the weights of the criteria. In filling the weights the criteria must meet a maximum of 100 weights. After that create a criteria scale along with a weight scale where this scale will later be used as the filling of each subsequent alternative criteria. After the alternative is done filling with the criteria scale, then the calculation of the decision matrix $\mathrm{X}$ and obtained the final value calculation. After calculating the final value is ranking, where each alternative will be sorted by the highest rank to the lowest. The steps of the Simple Additive Weighthing is below:

1. Choose Alternatives

The first step of using Simple Additive Weighting is choosing the alternatives. An alternative is a different object and has equal opportunities to be chosen by decision makers (Mude \& Mude, 2016). In this research the choosen alternatives are 15 to be samples.

2. Determine Criteria

Criteria should be determined before doing calculation. The purpose of the criteria is to be parameters of the calculation. Criteria used to assist in the decision search process to be more accurate to who is entitled to receive the highest rank (Oktaviani, Merlina, \& Nurmalasari, 2018).

3. Filling Weights of Criteria

After determined the criteria, the next step is filling all the criteria with weights. Weights of criteria are very important to have calculation perfecly. Weights in criteria are generally used as a reference as a calculation later (Fauzan, Indrasary, \& Muthia, 2018).

4. Determine Scala Criteria

In each of criteria has been made, scala is important to fill the alternatives. The Criteria Scale is generally used to compare with all existing alternative ratings (Putra, Aryanti, \& Hartati, 2018).

5. Fill the Alternatives with Scala.

After all 1-4 steps are finished, then to initialize the calculation is filling the alternatives with scala that has been made before.

6. Decision Matrix X and Normalize it

After filling the alternatives with the scala criteria is to move that into the decision matrix $\mathrm{x}$ and also normalize it with the formula:

$$
R i j=\frac{X i j}{\operatorname{Max}(i) x i j}
$$

Since all of the criteria is benefit criteria, then all the formula used like that. (Handayanna \& Dewi, 2020).

Final Calculation and Ranking

After normalize the matrix, then multiply the normalization matrix into the simplify weights of the criteria. The formula is (Nasir, 2019)

$\sum_{j}^{n}=1 W j R i j$

The formula will form the score of each every alternatives that has been filled and calculate before. The result of the score now can become ranking. 


\section{Data Collection Tehniques}

The data obtained in this study is the primary data of pesantren internal data. This data includes alternatives and criteria. Below is alternative and Criteria data obtained from pesantren

\section{Alternative Data}

Alternatives used in simple additive weighting scenarios is using alternatives data on Table 1.

\section{Criteria and Scala Data}

In the Table 2 below is a scenario of applying the criteria in the Simple Additive Weighting method where there are 4 criteria, each of which is a benefit type and has a total weight of all criteria is 100 weights.

Table 2. Scenario of Application of Criteria In Simple Additive Weighting Method.

\begin{tabular}{lllc}
\hline \multicolumn{3}{c}{ Criteria } & \\
\hline No & Criteria Name & Type & Weight \\
\hline C1 & Adab & Benefit & 10 \\
C2 & Akhlak & Benefit & 10 \\
C3 & Tahsin & Benefit & 10 \\
C4 & Tajwid & Benefit & 10 \\
C5 & Makhroj Huruf & Benefit & 10 \\
C6 & Disiplin & Benefit & 10 \\
C7 & Komitmen & Benefit & 10 \\
C8 & Loyalitas & Benefit & 10 \\
C9 & Ceramah & Benefit & 5 \\
C10 & Ibadah & Benefit & 10 \\
C11 & Perilaku Pada Santri & Benefit & 5 \\
\hline
\end{tabular}

In the table 3 below is the scale of each criteria specified using linkert scale and values from $1-5$. Where the lowest value is 1 that is with a scale of very less and a value of 5 for the highest scale

Table 3. Application of Criteria Scale on each. criteria

\begin{tabular}{clc}
\hline \multicolumn{2}{c}{ Scala Criteria } \\
\hline No & Scala & Score \\
\hline 1 & Sangat Kurang & 1 \\
2 & Kurang & 2 \\
3 & Cukup & 3 \\
4 & Baik & 4 \\
5 & Sangat Baik & 5 \\
\hline
\end{tabular}

RESULTS AND DISCUSSION

\section{Simple Additive Weighting Implementation}

This method is implement in the dynamic application called Decision Support System (DSS) that has been made. The figure 2 and figure 3 is below this:

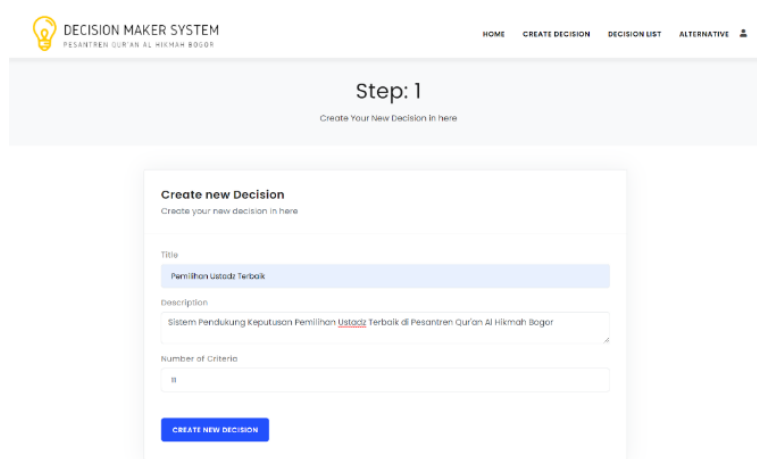

Figure 2. Create New Decision (Application)

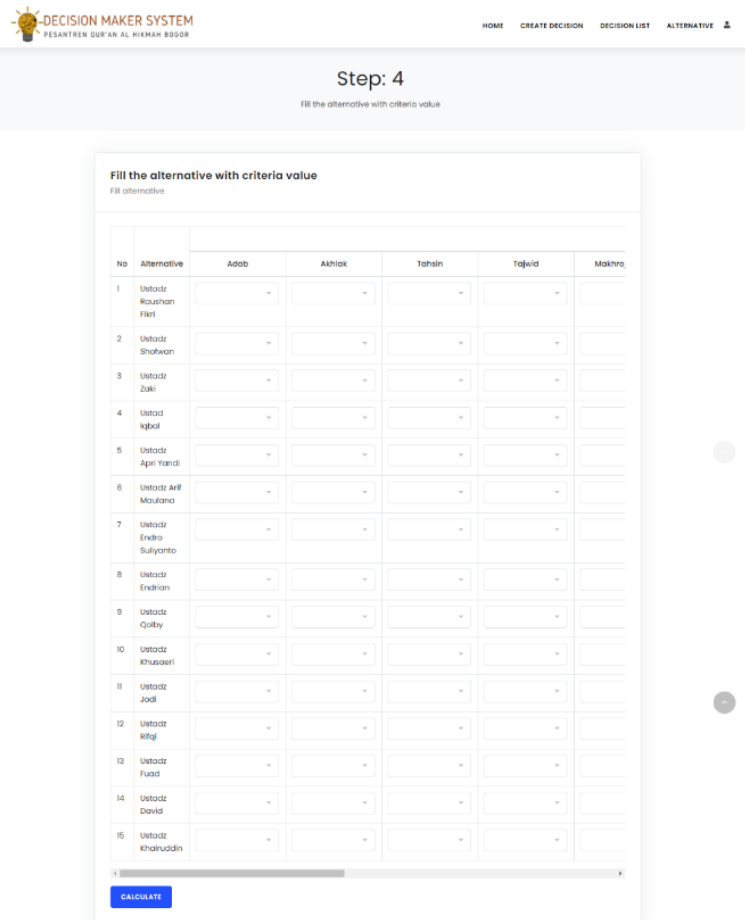

Figure 3. Filling Alternatives with Scala Criteria (Application)

There are 30 samples of data used to test the Decision Support System where each sample has different numbers. The 30 samples are used to put in the applications and put in calculate manual in excel. The table comparison between result of application and manual is Table 4 below: 
Table 4. Manual calculation comparison with application.

\begin{tabular}{|c|c|c|c|}
\hline Sample & Manual & Application & Result \\
\hline \multirow[t]{2}{*}{1} & Ustadz & Ustadz & Match \\
\hline & Khusaeri & Khusaeri & \\
\hline \multirow[t]{2}{*}{2} & Ustadz & Ustadz & Match \\
\hline & Khairuddin & Khairuddin & \\
\hline \multirow[t]{2}{*}{3} & Ustadz & Ustadz & Match \\
\hline & Khairuddin & Khairuddin & \\
\hline 4 & Ustadz Rifqi & Ustadz Rifqi & Match \\
\hline 5 & Ustadz Iqbal & Ustadz Iqbal & Match \\
\hline 6 & Ustadz Rifqi & Ustadz Rifqi & Match \\
\hline \multirow[t]{2}{*}{7} & Ustadz & Ustadz & Match \\
\hline & Endrian & Endrian & \\
\hline 8 & Ustadz Rifqi & Ustadz Rifqi & Match \\
\hline \multirow[t]{2}{*}{9} & Ustadz & Ustadz & Match \\
\hline & Endrian & Endrian & \\
\hline \multirow[t]{2}{*}{10} & Ustadz & Ustadz & Match \\
\hline & Endrian & Endrian & \\
\hline \multirow[t]{2}{*}{11} & Ustadz & Ustadz & Match \\
\hline & Shofwan & Shofwan & \\
\hline \multirow[t]{2}{*}{12} & Ustadz & Ustadz & Match \\
\hline & Endrian & Endrian & \\
\hline 13 & Ustadz Jodi & Ustadz Jodi & Match \\
\hline \multirow[t]{2}{*}{14} & Ustadz & Ustadz Fuad & Not \\
\hline & Shofwan & & Match \\
\hline 15 & Ustadz Iqbal & Ustadz Iqbal & Match \\
\hline 16 & Ustadz Zaki & Ustadz Zaki & Match \\
\hline \multirow[t]{2}{*}{17} & Ustadz Zaki & Ustadz Jodi & Not \\
\hline & & & Match \\
\hline 18 & Ustadz Rifqi & Ustadz Rifqi & Match \\
\hline 19 & Ustadz David & Ustadz David & Match \\
\hline \multirow[t]{2}{*}{20} & Ustadz Apri & Ustadz Apri & Match \\
\hline & Yandi & Yandi & \\
\hline 21 & Ustadz Fuad & Ustadz Fuad & Match \\
\hline \multirow[t]{2}{*}{22} & Ustadz & Ustadz & Match \\
\hline & Khairuddin & Khairuddin & \\
\hline \multirow[t]{2}{*}{23} & Ustadz & Ustadz & Match \\
\hline & Khairuddin & Khairuddin & \\
\hline \multirow[t]{2}{*}{24} & Ustadz & Ustadz & Match \\
\hline & Khairuddin & Khairuddin & \\
\hline \multirow[t]{2}{*}{25} & Ustadz & Ustadz & Match \\
\hline & Khairuddin & Khairuddin & \\
\hline \multirow[t]{2}{*}{26} & Ustadz & Ustadz Rifqi & Not \\
\hline & Khairuddin & & Match \\
\hline \multirow[t]{2}{*}{27} & Ustadz & Ustadz & Match \\
\hline & Khairuddin & Khairuddin & \\
\hline \multirow[t]{2}{*}{28} & Ustadz & Ustadz & Match \\
\hline & Khairuddin & Khairuddin & \\
\hline \multirow[t]{2}{*}{29} & Ustadz & Ustadz & Match \\
\hline & Khairuddin & Khairuddin & \\
\hline \multirow[t]{2}{*}{30} & Ustadz & Ustadz & Match \\
\hline & Khairuddin & Khairuddin & \\
\hline
\end{tabular}

Based on Table 4 above found 3 differences between manual and application calculations in samples 14,17 and 26 . So out of the 30 samples available, the similarity of the first ranking results in the comparison between manual and application calculations is 27 similarities. So that it can be taken into account the accuracy as follows.

$$
\text { Accuracy }=\frac{27}{30} \times 100 \%
$$

The final result of the accuracy calculation is $90 \%$.

\section{CONCLUSIONS AND SUGGESTIONS}

\section{Conclusion}

Based on the research that has been made, it can be concluded that the best ustadz election decision support system is easier to use than counting manually. In addition, in avoiding the appointment of the best ustadz directly can be much more objective using this system. The level of accuracy in the comparison of manual calculations with application calculations is found to be $90 \%$. The system created can also shorten the time in helping to support the selection of the best ustadz.

\section{Suggestion}

The results of this application still feel far from perfect, so for further research will be done better development such as:

1. Can be tried with other methods to make decisions more effective.

2. Steps from filling alternatives with the criteria scale should be shortened again. So that users can be faster in filling decisions.

3. Results from rankings should be made more interactive as examples of added graphs.

\section{REFERENCES}

Deffit Saputra, M. (2019). Implementasi Metode Simple Additive Weighting (Saw) Untuk Menyeleksi Pemilihan Lurah Pondok (Studi Kasus: Pondok Pesantren Al-Munawwir Krapyak Komplek “L”). University of Technology Yogyakarta, Yogjakarta.

Fauzan, R., Indrasary, Y., \& Muthia, N. (2018). Sistem Pendukung Keputusan Penerimaan Beasiswa Bidik Misi di POLIBAN dengan Metode SAW Berbasis Web. Jurnal Online Informatika, 2(2), 79-83. https://doi.org/10.15575/JOIN.V2I2.101

Handayanna, F., \& Dewi, F. (2020). Implementation of Simple Additive Weighting Method As A Decision Support For New Student Admission In Madrasah Aliyah. Jurnal Riset Informatika, 2(2), $\quad$ 77-82. https://doi.org/10.34288/JRI.V2I2.129

Mude, M., \& Mude, M. A. (2016). Perbandingan 
Metode SAW dan TOPSIS pada kasus UMKM. ILKOM Jurnal Ilmiah, 8(2), 76-81. https://doi.org/10.33096/ilkom.v8i2.49.76-81

Mundiri, A., \& Zahra, I. (2017). Corak Representasi Identitas Ustadz dalam Proses Transmisi Pendidikan Karakter di Pesantren. Jurnal Pendidikan Islam Indonesia, 2(1), 21-35. https://doi.org/10.35316/JPII.V2I1.58

Muslihudin, M., Triananingsih, F., Kasmi, K., \& Anggraei, L. (2017). Pembuatan Model Penilaian Indeks Kinerja Dosen Menggunakan Metode Fuzzy Simple Additive Weighting. SEMNASTEKNOMEDIA ONLINE, 5(1), 3-5-25. Retrieved from https://ojs.amikom.ac.id/index.php/semnaste knomedia/article/view/1656

Nasir, jamal A. (2019). Sistem Pendukung Keputusan Pemberian Beras Untuk Keluarga Miskin Dengan Metode Simple Additive Weigthing. Jurnal Riset Informatika, 1(3), 134-138.

Nurdiyanto, H., \& Meilia, H. (2016). Sistem Pendukung Keputusan Penentuan Prioritas Pengembangan Industri Kecil Dan Menengah Di Lampung Tengah Menggunakan Analitical Hierarchy Process. SEMNASTEKNOMEDIA ONLINE, 4(1), 3-3-37. Retrieved from https://ojs.amikom.ac.id/index.php/semnaste knomedia/article/view/1163

Oktaviani, N., Merlina, N., \& Nurmalasari, N. (2018).
Pemilihan Jasa Pengiriman Terbaik Menggunakan Metode Simple Additive Weighting (SAW). JUSTIN (Jurnal Sistem Dan Teknologi Informasi), 6(4), 223-229. https://doi.org/10.26418/JUSTIN.V6I4.29126

Putra, A. S., Aryanti, D. R., \& Hartati, I. (2018). Metode SAW (Simple Additive Weighting) sebagai Sistem Pendukung Keputusan Guru Berprestasi ( Studi Kasus : SMK Global Surya). Prosiding Seminar Nasional Darmajaya, 1(1), 85-97. Retrieved from https://jurnal.darmajaya.ac.id/index.php/PSN D/article/view/1233

Syafe'i, I. (2017). Pondok Pesantren: Lembaga Pendidikan Pembentukan Karakter. AlTadzkiyyah: Jurnal Pendidikan Islam, 8(1), 6182. https://doi.org/10.24042/ATJPI.V8I1.2097 Usman, M. A., Santoso, E., \& Hidayat, N. (2017). Sistem Pendukung Keputusan Pemilihan Anggota Pengurus Harian Pondok Pesantren Menggunakan Metode Profile Matching (Studi Kasus Pondok Pesantren Putra Sabilurrosyad). Jurnal Pengembangan Teknologi Informasi Dan Ilmu Kompute, 1(10), 1176-1184. Retrieved from https://jptiik.ub.ac.id/index.php/jptiik/article/view/386 